\title{
Hukum Represif dan Sistem Produksi Hukum yang Tidak Demokratis
}

\author{
S. Brodjo Soedjono
}

\begin{abstract}
Tentang "negara hukum", "supremasi hukum", dan equality before the law, tersurat jelas dalam Konstitusi, UU, dan doktrin hukum. Bahkan aparat penegak hukum tak henti-henti "mendeklarasi" setiap kali. Namun jika Anda bertanya, mengapa ketiga "hakikat asasi" hukum itu tidak menemukan rujukan empiriknya dalam dunia hukum Indonesia? Jawabannya, karena dominasi kekuasaan atas hukum. Itulah hukum represif.
\end{abstract}

\section{Pengantar}

Indonesia adalah negara hukum. penguasa daripada kehendak rakyat. Konstitusi mengatur begitu tegasnya. Kekuasaan dan hukum, praktis menjadi dua Supremasi hukum, terelaborasi begitu jelas dalam dogma, doktrin, dan UU. Soal keharusan penegakkan hukum tanpa pandang bulu (equality before the law), pemerintah dan aparat penegak hukum selalu didengungkan nyaring. Namun ketiganya yang terabaikan.

Itulah yang riil terjadi. Kekuasaan lebih utama dari hukum. Penegak hukum seolah lebih "terpesona" pada "bulu" yang dihadapinya ketimbang kepastian dan keadilan. Produk legislasi lebih mencerminkan kemauan entitas yang menjalin diri dengan sangat menyatu - di mana hukum dibuat dan disahkan oleh kesadaran kekuasaan sebagai anak sulung - yang senantiasa berusaha menerobos ke celah-celah yang mudah direkayasa sehingga hukum lebih dirasakan sebagai alat penguasa, ketimbang sebagai kontrolkekuasaan.'

Pembatasan kebebasan menyampaikan pendapat lewat UU No. 9/1998, pemaksaan UU Penanggulangan Keadaan Bahaya, dan

"Fenomena umum dalam hukum modem menyangkut "persaingan" antara hukum dan kekuasaan, ditandai oleh dua kecenderungan. Yang satu, ketertutupan sistem hukum terhadap kekuasaan. Sedangkan yang lain, serba dominasi kekuasaan atas hukum. Hasil akhir dari dua kondisi tersebut, berujung pada ketakmampuan hukum sebagai sarana mengarahkan perubahan dan pencapaian perubahan (Lihat Philippe Nonet \& Philip Selznick. 1978. Law and Society in Transition: Toward Responsive Law. London: Harper and Row Publisher. hlm. 4. 
ketiadaan aturan peralihan dalam UU No. 31/ 1999, merupakan sekelumit contoh betapa kuatnya cengkeraman kekuasaan dalam produksi hukum. Kemacetan proses hukum KKN Soeharto dan kroni-nya, penculikan Aktivis Demokrasi, dugaan suap AM Ghalib, sangkaan korupsi Beddu Amang, serta skandal Bank Bali dan Texmaco, adalah contoh lain dalam penegakan hukum yang menunjukan betapa "hukum kekuasaan", dan. bukan "kekuasaan hukum" masih ada di alam reformasi.

Fenomena instrumentasi hukum bagi kepentingan kekuasaan ${ }^{2}$ seperti dalam contoh di atas, disebut Nonet dan Selznick sebagai hukum represif. ${ }^{3}$ Tipe hukum represif ini secara kategorial oleh Nonet dan Selznick dibedakan dengan dua tipe yang lain, yaitu hukum otonom ${ }^{4}$ dan hukum responsif. ${ }^{5}$ Tulisan ini membatasi diri pada persoalan produksi hukum yang tidak demokratis sebagai sebab lahimya hukum represif. Oleh karena itu, selain bagian pengantar di atas, makalah ini juga terdiri dari empat bagian lain. Yaitu: (1) Hukum represif; (2) Anatomi produksi hukum yang tidak demokratis, (3). Akibat hukum represif, (4). Jalankeluar sebagai penutup.

\section{Hukum Represif}

Sebelum membahas persoalan produksi hukum yang tidak demokratis sebagai sebab lahimya hukum represif, dipandang perlu untuk sekilas menelusuri "anatomi" hukum represif itu sendiri. Sebab, hanya apabila apa yang dimaksudkan itu telah jelas, maka kita dapat mengusulkan langkah-langkah untuk mengakhirinya. Nonet dan Selznick memberi perhatian khusus pada variabel-variabel yang berkaitan dengan hukum (represif), yaitu: peran paksaan dalam hukum, hubungan antara hukum dan politik, negara, moral, serta tempat diskresi dan tujuan dalam keputusankeputusan hukum. ${ }^{6}$

Secara ringkas, "anatomi" hukum represif terurai dalam paling sedikit sepuluh ciri utama.' (1). ketertiban menjadi tujuan utama hukum; (2). legitimasi atau dasar kekuatan mengikatnya adalah kekuasaan negara; (3). peraturan-peraturannya yang terumus secara

2lbid. hlm. 29.

${ }^{3}$ hukum represif, yaitu hukum sebagai alat kekuasaan represif. Tipe hukum ini bertujuan mempertahankan status quo penguasa yang kerapkali diterapkan dengan dalih menjamin ketertiban. Dengan demikian, hukum ini diumuskan secara rinci untuk mengikat setiap orang, kecuali penguasa/pembuat hukum (/bid, hlm. 29-52).

"hukum otonom, yaitu hukum sebagai suatu pranata yang setia menjaga kemandirian hukum itu sendiri. Karena sifatnya yang mandiri, maka yang dikedepankan adalah pemisahan yang tegas antara kekuasaan dengan hukum. Legitimasi hukum ini terletak pada keutamaan prosedural hukum yang bebas dari pengaruh politik melalui pembatasan prosedur yang sudah mapan (lbid, hlm. 53-72).

${ }^{5}$ hukum responsif, yakni hukum sebagai sarana respons terhadap ketentuan-ketentuan sosial dan aspirasi publik, Sesuai dengan sifatnya yang terbuka, maka tjpe hukum ini mengedepankan akomodasi untuk menerima perubahan-perubahan sosial demi mencapai keadilan dan emansipasi publik (lbid, hlm. 73-113).

${ }^{6}$ Lewat pemaparan sekalian variabel tersebut, Nonet dan Selznick mengajukan tiga teori tersebut untuk menjelaskan hubungan-hubungan sistemik dalam hukum dan konfigurasi khusus di mana hubungan-hubungan tersebut terjadi.

${ }^{7}$ lbid, him. 9. 
rinci bersifat keras (represif) mengikat rakyat, tapi lunak terhadap penguasa; (4). alasan pembuatannya bersifat ad-hoc sesuai keinginan arbitrer penguasa; (5). kesempatan bertindak bersifat serba meresap sesuai kesempatan; (6). pemaksaan serba mencakupi tanpa batas yang jelas; (7). moralitas yang dituntut dari masyarakat adalah pengendalian diri; (8). kekuasaan menempati posisi di atas hukum; (9). kepatuhan masyarakat harus tanpa syarat, dan ketidakpatuhan dihukum sebagai kejahatan; (10). partisipasi masyarakat dijjinkan lewat penundukkan diri, sedangkan kritik dipahami sebagai pembangkangan.

Dari konstelasi hubungan antarvariabel itu, jelaslah bahwa hukum represif merupakan sistem hukum kekuasaan represif yang bertujuan mempertahankan kepentingan penguasa -yang kerapkali diterapkan dengan dalih menjamin ketertiban. Karena hukum merupakan alat penguasa, maka dalam geraknya aturan-aturan hukum tidak mengikat penguasa sebagai pembuatnya. Sebaliknya, ia berfungsi mengendalikan seluruh aspek kehidupan rakyat yang dirancang secara sentral - untuk menciptakan, melaksanakan, serta memperkuat kontrol terhadap segenap kegiatan masyarakat. $^{8}$

Konfigurasi sistem hukum yang demikian, tak pelak lagi memunculkan wajah hukum yang memihak pada penguasa. Persis di titik ini, hukum represif bersimetris dengan apa yang oleh Podgorecki disebut hukum otoriterian. Yakni suatu sistem hukum dengan ciri: Pertama, substansi hukumnya berisi peraturan yang mengikat sepihak dan materinya berubah-ubah sesuai keinginan yang bersifat arbitrer sang penguasa.

Kedua, aturan hukum dipakai sebagai kedok dengan cara yang "lihai" untuk menutupi intervensi kekuasaan yang berlebihan. Ketiga, "penerimaan" masyarakat terhadap hukum berjalan dalam kesadaran palsu. Keempat, sanksi-sanksi hukum, potensiil menimbulkan keberantakan sosial (social disintegration), dan nihilisme sosial menyebar tak terkendali. Kelima, tujuan akhir hukum adalah legitimasi institusional yang lepas dari persoalan diterima tidaknya oleh masyarakat.

Pembusukan hukum dan lestarinya KKN pada masa Orla dan Orba - yang sampai derajat tertentu masih kokoh hingga sekarang, justru karena penggunaan kekuasaan yang tidak terbatas oleh penguasa dalam menentukan materi, bentuk produk hukum, dan penggunaannya-untuk diabdikan bagi kepentingan penguasa dan para kroni-nya. Dengan didukung oleh perencanaan yang sistematis lewat peraturan-peraturan yang diusulkan dan dibuatnya (UU, PP, Kepres, Inpres, Kepmen dan lain-lain), pemerintah melakukan intervensi secara "syah" dan Ieluasa dalam tiap relung kehidupan rakyat. Tak pelak lagi, sistem hukum lebih mewajah selera penguasa ketimbang kepentingan rakyat. ${ }^{10}$

$8 /$ bid. hlm. 52.

"Uraian menyeluruh tentang hukum totalitarian, dapat dibaca dalam Adam Podgorecki. 1996." Totalitarian Law: Basic Consepts and Issues". dalam Totalitarian and Post-Totalitarian Law. Pogorecki \& Oligiati (eds.).

${ }^{10}$ Dalam skema teori klasik Dahrendorf, penguasaan penguasa atas rakyat dapat dilihat sebagai akibat semata dari hubungan yang tak seimbang' antara pemegang otoritas dengan rakyat yang diperintah (Ralf Dahrendorf. 1954. Class and Class Conflict in Industrial Society Stanford. University Press. hlm. 176. 
Tentu saja produk hukum yang demikian, pada dirinya bertentangan dengan Asas legalitas sebagai asas hukum yang paling dasar dan semesta yang dianut negaranegara demokrasi. Dari sejarahnya, asas ini lahir sebagai reaksi terhadap kelaliman penguasa Ancien Regime di Eropa Barat Abad ke-17 dan 18. Pada masa itu, penguasa bersama Gereja yang tergabung dalam Standestaat, menjalankan kekuasaan yang totaliteristik - sehingga hak-hak asasi rakyat diabaikan bahkan diinjak-injak.

Berkat ketajaman pena para cendikia seperti, Mentesquieu, Voltaire, Beccaria, dan De Sanan, telah mengilhami kaum borjuis dengan energi kapitalnya, untuk berjuang menjatuhkan keangkuhan Standestaat dengan feodalismenya, sehingga demokrasi beserta Rule of Law dinobatkan menjadi tatanan baru kehidupan yang demokratis." Itulah sebabnya, sebagai "asas pembebasan", asas legalitas bersama asas-asas lain seperti, asas kesamaan, publisitas, proporsionalitas, dan subsidiaritas, berfungsi sebagai asas kritis-normatif terhadap kekuasaan. Sekalian asas itu, selain dijadikan ukuran untuk menilai kewajaran penggunaan kekuasaan penguasa terhadap rakyat, juga sekaligus berfungsi mengatur "garis demarkasi" kehidupan rakyat yang boleh atau tidak boleh dimasuki oleh kekuasaan penguasa.

Dua fungsi itu secara implisit tersirat dalam pasal 1 ayat (1) Kitab Undang Undang Hukum Pidana yang berbunyi: 'Tiada suatu perbuatan dapat dipidana kecuali atas kekuatan aturan pidana dalam perundang-undangan yang telah . ada, sebelum perbuatan dilakukan." Ketentuan pasal 1: $1 \mathrm{KUHP}$ yang juga sangat dikenal dengan sebutan asas legalitas.

Menurut Nico Keijzer, ${ }^{12}$ asas legalitas mempunyai dua fungsi dasar, yaitu: Fungsi perlindungan, artinya undang-undang pidana berfungsi untuk melindungi rakyat terhadap pelaksanaan kekuasaan tanpa batas oleh pemerintah. Di samping fungsi melindungi, undang-undang pidana juga mempunyai fungsi instrumental, artinya di dalam batasbatas yang ditentukan oleh undang-undang pelaksanaan kekuasaan oleh pemerintah untuk menuntut setiap orang yang melanggar, tegas-tegas diperbolehkan.

Pasal 1: 1 KUHP berkaitan pula dengan keharusan untuk adanya jaminan prosedur yang memadai dan kepastian hukum dalam hukum pidana. Oleh karena itu, dimensi lain yang tercakup dalam asas legalitas adalah dimensi politik hukum yang berarti perlakuan yang sama di depan hukum bagi semua orang tanpa kecuali. Asas perlakuan yang sama inilah menjadi landasan perindungan hak asasi manusia dalam hukum pidana.

\section{Anatomi Produksi Hukum yang Tidak Demokratis}

Tentang sebab terjadinya produksi hukum yang tidak demokratis, diduga selain macetnya kontrol publik (eksternal) baik pers maupun

"Lih. Gianfranco Poggi. 1978. The Development of the Modern State. A Sociological Introduction. London: Hurchinson \& Co. Ltd.

${ }^{12}$ Nico Keijzer. 1989. "Legaliteitsbeginsel". Makalah pada Penataran Nasional Hukum Pidana Angkatan III Kerjasama Indonesia-Belanda di Kupang. 30 Juli sampai dengan 19 Agustus. hlm. 3 - 4. 
lembaga-lembaga kontrol lainnya, terdapat sejumlah faktor penentu dalam sistem produksi hukum yang memang tidak demokratis.

Pertama, proses legislasi yang terpusat pada eksekutif. Selama pemerintahan Orba, hampir semua RUU berasal dari lingkungan eksekutif, termasuk RUU mengenai tata tertib DPR sendiri berasal dari eksekutif. Bahkan dalam geraknya, menteri-menteri sebagai pembantu presiden mempunyai "wewenang" yang jauh lebih kuat daripada anggota DPR dalam menentukan bobot dan kelayakan materi RUU menjadi UU. Hal yang sama terjadi di tingkat provinsi dan kabupaten. Gubernur dan Bupati lebih "berkuasa" daripada DPRD.

Kedua, formasi keanggotaan DPR/DPRD yang dikehendaki pasal 19 UUD'45 sedemikian rupa didesain menjadi dua kelompok: "wakil pilihan rakyat" dan "wakil promosi" dari kalangan militer dan polisi. Komposisi yang demikian, menimbulkan distorsi kedaulatan rakyat —apalagi di masa Orba "wakil promosi" itu menjadi kawan seiring dengan Golkar yang bertindak sebagai partai penguasa.

Ketiga, sebagai akibatnya, RUU bawaan pemerintah yang memang jarang ditolak DPR (kecuali terjadi reaksi keras publik), adalah pesanan hasil tawar-menawar eksekutif dengan pihak luar, sehingga tidak jarang materinya berupa duplikasi dan atau terjemahan dari "dokumen" tertentu.

Keempat, pembahasan RUU di DPR pun lebih sering berkutat pada persoalan redaksional dengan kurang menggugat substansi apalagi semangat di balik paket RUU itu.

Kelima, penyusunan rancangan suatu RUU seringkali hanya menjadi persoalan ahli hukum. Padahal sebagai sebuah institusi sosial, hukum menjangkau lebih dari sekedar urusan teknis hukum. la juga berurusan dengan persoalan manajemen sosial yang tidak bisa tidak, harus melibatkan ahli-ahli lain seperti sosiologiwan dan antropologiwan untuk menyebut beberapa saja.

Keenam, proses penyusunan RUU dari pemerintah pun ternyata merupakan urusan segelintir staf ahli dalam lingkungan birokrasi yang begitu elitis. . Ada pun draf akademik yang melibatkan pihak universitas, acapkali terbentur pada pertelingkahan ilmiah objektif dan politik pragmatis.

Kelemahan mendasar produk hukum tersebut, justru terletak di sini. Atas nama "kepentingan nasional", desain produksi hukum diorientasikan pada apa yang dikenal unifikasi primitif. ${ }^{13}$ Yaitu, proses penundukan sekalian aspirasi rakyat pada sebuah otoritas yang bersifat monolitik: satu subjek (bertolak dari penguasa), satu makna (menurut konsep penguasa), satu tindakan (yang diingini penguasa), dan satu akibat (sesuai target penguasa). ${ }^{14}$

Proses legalisasi kekuasaan penguasa tersebut menjadi serba meliputi (embracing), ketika mesin administrasi pemerintahan

\footnotetext{
${ }^{13}$ Ini merupakan ekses dari etika mikro liberal, yang menurut Santos telah menjadi konsepsi dominan di dalam rasionalitas moral praktis modernisasi. Lihat B. De Sousa Santos. 1995. Toward A New Common Sense: Law, Science and Politics In Paradigmatic Transition. New York: Routledge.

${ }^{14} \mathrm{Bagi}$ Santos. etika liberal beroperasi melalui urut-urutan linier: satu subjek, satu tindakan, dan satu akibat (lbid., him. 50).
} 
dibiarkan memproduksi serbaneka kebijakan publik tanpa kontrol yang memadai. Alhasil, bukan saja terjadi inflasi kebijakan publik yang sarat KKN, tetapi juga hakikat pemerintah sebagai pelaksana kehendak rakyat-yang idealnya setiap saat siap mempertanggungjawabkan . segala kebijakan-dengan mudah berbalik sebagai penguasa yang mendikte rakyat. ${ }^{15}$

Oleh karena itu, kerap kali apa yang disebut hukum, bukan berisi tentang apa yang dipandang perlu oleh rakyat untuk diatur, melainkan apa yang menurut pemerintah perlu untuk mengatur bahkan menekan rakyat. Meminjam Foucault, rasionalitas kekuasaan seperti ini tidak kurang naluri will to power. ${ }^{16}$ Yakni suatu rasionalitas "penyebaran dominasi". ${ }^{17}$ Inilah yang menjadi saiah satu penjelasan mendasar, mengapa segala keberatan rakyat atas ketakberesan penguasa masa lalu, selalu dipasung dengan inkonstitusional, melawan hukum, melanggar UU, dan ungkapanungkapan lain yang semakna seperti, melawan pemerintah, makar, anarkhi, serta yang paling kejam, separatisme GPK, PKI dan anti Pancasila.

Akibatnya, aturan hukum menjadi tumpukan legislasi yang tidak terpikirkan (unthinking law) oleh rakyat, karena berada di luar kepentingan dan tangkapan rasa mereka. ${ }^{18}$ Fenomena itu, dengan mudah ditemukan dalam tumpukan "Keppres Orba" yang "dievaluasi" "Masyarakat
Transparansi Indonesia" (MTI). Dari 528 buah Keppres yang ditelorkan Soeharto minus 118 buah Keppres hasil ratifikasi perjanjian internasional selama periode lima tahun (1993-1998), terdapat 79 buah yang oleh MTI dinilai bermasalah.

Seperti perundang-undangan bidang politik di masa Orba, puluhan keppres yang bermasalah itu menjadi bukti tentang penggunaan kekuasaan yang tidak terbatas oleh penguasa dalam menentukan materi dan bentuk produk hukum - untuk diabdikan bagi kepentingan penguasa dan para kroni-nya. Kenyataan itu juga memperlihatkan sikap kesewenangan penguasa memanipulasi hukum untuk menjustifikasi tindakannya yang merugikan rakyat.

\section{Akibat Hukum Represif}

Mengamati carut-marut proses penegakkan hukum selama ini, paling sedikit ada dua "sindrom" besar yang menyeruak ke permukaan. Yang satu adalah, "sindrom" instrumentalisme hukum menurut naluri kepentingan yang bersifat arbitrer. Sedangkan yang lain, gejala "pencairan" hukum menurut kesempatan yang "ditawarkan".

Sindrom pertama, permainan "Kiri-Kanan Oke". Meski menurut logika Lex Certa, ketentuan-ketentuan hukum yang terumus rinci menjadi jaminan kepastian hukum, namun

${ }^{15}$ Bandingkan dengan Franc L. Neumann. 1986. The Rule of Law. Political Theory and Legal System in Modern Society. New Hampshire: Berg Publisher Ltd.

"Lih. dalam F.B. Hardiman. 1993. "Mengatasi Paradoks Modemisasi", dalam Diskursus Kemasyarakatan dan Kemanusiaan. Jakarta: Gramedia. hIm. 156.

${ }^{17}$ lbid.

${ }^{18}$ Bonaventura de Sousa Santos. Toward A New Common Sense..., Op. Cit. hlm. 51. 
kerigidan itu menjadi "bersayap" manakala berangkulan dengan naluri kepentingan. la bisa menjadi keras (represif) mengikat pihak tertentu, tapi juga akan lunak terhadap pihak lain-tergantung siapa dulu "ibu" atau "bapak"nya. "Sindrom" itu dengan mudah kita tangkap lewat hamparan kasus yang tergelar aneh selama ini.

Ketentuan ijin untuk demonstrasi ditegakkan mati-matian menghadapi massa yang berunjuk rasa, tapi pelaku penembakan Trisakti dan Semanggi tak tersentuh pasal pembunuhan. Pasal makar serta-merta ditimpakan tanpa ampun pada para "eksponen" Barisan Nasional, tapi penculikan penuh muslihat (gimmick) terhadap Aktivis Demokrasi dibiarkan tertelan waktu.

Dalam kasus. KKN mantan presiden Soeharto, sangkaan suap AM Ghalib, dan skandal Bank Bali, terlihat jelas bahwa intervensi dan cengkeraman kekuasaan begitu kuat dalam law enforcement. Perihal proses hukum mantan presiden Soeharto, baik perintah Tap MPR No. XI/1998 mau pun standar pembuktian KUHAP dan UU No. 3/ 1971, bukannya menjadi peluang pemeriksaan, tetapi menjadi sumber "involusi"-yang menggantung di antara kepastian hukum dan kelenturan politik. Fakta/bukti yang "disodorkan" berbagai pihak, tidak diperlakukan sebagai "laporan adanya tindak pidana" menurut logika pasal 7 (1) huruf a KUHAP. Kejaksaan Agung kala itu, lebih memilih bersikap pasif ketimbang pro-aktif mengambil langkah-langkah penyidikan, seperti diperintahkan oleh pasal $5,11,12$, UU No. $3 / 1971$ dan yang dimungkinkan oleh pasal 7 (1) huruf $d, e, g, h, j$ KUHAP.

Menyangkut sangkaan suap Jaksa Agung non-aktif AM Ghalib, transfer dana dari pengusaha yang sementara diperiksa
Kejagung ke rekening pribadi sang Jaksa Agung, bukannya diperiksa sebagai penyuapan atau korupsi, tetapi dibelokkan ke jalur non-hukum untuk diaudit Menkowasbangyang tentu di luar kepentingan penyidikan. Sejumlah rekening bermasalah tidak dapat diusut karena Puspom TNI enggan "memasuki" ruang penyidikan. Sikap Puspom yang mengintrodusir "status terlapor" pada AM Ghalib, tidak saja membuat yang bersangkutan terhindar dari proses penyidikan. Juga tidak hanya menyebabkan bagian terbesar rekening bermasalah AM Ghalib aman dalam "lindungan" kerahasiaan Bank versi UU No. 10/1998. la juga, secara mengagumkan menikmati status "dilepas bersyarat" hingga ada orang yang mampu menyerahkan bukti hukum tentang rekening-rekening bermasalah itu-tanpa melangkahi prosedur UU No. $10 /$ 1998. Sebuah mission imposible, bukan?

Serupa dengan kasus AM Ghalib, puluhan oknum pejabat dan rekening yang tersangkut dalam distribusi dan pengembalian uang haram milik BB, dijadikan informasi rahasia. Meski auditor independen Pricewaterhouse Coopers (PwC) dengan susah payah merekam lika-liku permainan busuk tersebut dalam long form report sebanyak 400 halaman, namun BPK berusaha. "mengedit" dalam bentuk "abstraksi" 36 halaman yang sangat kabur.

"Sindrom" kedua, adalah mencairnya hukum di tangan penegaknya.. Jika dilihat ke belakang, setumpuk "kasus besar" terpaksa menjadi sekedar "kisah fantasi hukum" berkat kepandaian aparat menggunakan kesempatan. Batalnya eksekusi putusan Kasasi dalam kasus Ohee yang diterpedo "Surat sakti" Ketua MARI No. KMA/126/1995, kesalahan prosedur dalam kasus Gandhi Memorial School, serta 
pembatalan putusan kasasi lewat PK jaksa dalam perkara Muchtar Pakpahan-untuk menyebut beberapa saja.

Sebenarnya secara hukum, sekalian kasus itu terbilang biasa. Keputusan yuridis berdasarkan prosedur normal sudah diambil. Tapi mengapa "kepastian" itu masih bisa diterobos secara "yuridis" pula? Jawabannya, karena bentangan kewenangan yang dimiliki aparat sebagai pejabat/pelaksana hukum, memungkinkan terjadinya pen-"cair"-an hukum. Mereka memiliki kuasa untuk menentukan ruang-lingkup bukti yang perlu dikumpulkan. Mereka pula yang "memaknai" bukti mana yang tergolong bukti hukum dan mana yang tidak. Mereka mempunyai kewenangan untuk menentukan siapa yang perlu ditahan dan siapa yang tidak. Bahkan mereka berkuasa menetapkan status hukum seseorang dsb. Sekalian kewenangan itu, niscaya memberi peluang bagi terjadinya transaksi "saling tindak" dan "saling ucap" dalam "logika resiprositas" (saling bayar kewajiban).

Menurut Charles Sampford, penegak hukum sebagai "pemikul tugas", tidak hanya mengabdi kepada hukum, tetapi juga terikat pada "logika" kepentingan lain di luar hukum. Kalkulasi kepentingan di luar kenormalan logika hukum umum seperti itu, dijelaskan Sampford sebagai fenomena legal melee. ${ }^{19}$

Kata melee -dipakai Sampford sepadan dengan fluid- untuk menunjuk pada mencairnya hukum di tangan seorang pejabat' pelaksana hukum (law occupant). Meski idealnya, bangunan hukum itu harus sistemik -dalam arti ada kejumbuhan antara aturan, pelaksanaan, dan tujuannya, namun seperti dikatakan Sampford, harapan itu acapkali tidak terwujud- karena masuknya kepentingan "baru" yang begitu aktif menghiasi "sistem situasi" pelaksananya.

Kepentingan tersebut tidak harus murni bersifat subjektif dan berada jauh di luar lembaga hukum. Sebaliknya, kepentingan itu, justru muncul dalam lingkaran hukum itu sendiri, entah karena aturan hukum itu sendiri mebuka pelaung, ataupun karena kekuasaan dan kewenangan yang dimilikinya sebagai pejabat/pelaksana hukum dalam lingkungan (kerja) masing-masing. Justru karena jabatannya, maka sesungguhnya dalam diri seorang pejabat/pelaksana hukum, niscaya selalu tersimpul dua "motif". Yang satu, adalah motif pemegang wewenang yang memiliki kuasa tertentu untuk menentukan arah pelaksanaan hukum. Sedangkan yang lain, ialah motif pemakai wewenang yang menjinjing kepentingan tertentu, dan bila dipandang periu dapat diselipkan pada sarana (aturan) yang dipakainya.

Kenekatan Jaksa Penuntut Umum mengajukan PK dalam perkara Muchtar Pakpahan misalnya, merupakan contoh paling teras dari fenomena kepentingan yang demikian itu. Ketiadaan rumusan hukum yang eksplisit melarang JPU mengajukan PK, tidak terutama ditangkap sebagai larangan-seperti lazim logika normal hukum. Dengan "kekuasaan" dan "kewenangan"-nya sebagai

${ }^{9}$ Tentang logika Legal Melee. Lihat Sampford. 1989. The Disorder of Law: A Critique of Legal Theory. New York: Basill Blackwell Inc. 
pejabat yang berhadapan dengan terdakwa, JPU menangkap ketidaktegasan aturan itu sebagai kesempatan hipotetis. Jadi kemungkinan terjadinya pergantian tujuan (goal-substitution-goal-displacement) dari tujuan "asali" ke tujuan "cadangan" merupakan keniscayaan pula.

Penyelenggaraan hukum yang demikian telah menelorkan efek ganda yang ujungujungnya membentuk "piramida korban rakyat". Yang satu, rezim Orba terseret dalam otoritarianisme. Melalui "Sapujagat" tentang gambaran kelam kiprah penguasa (Orba) yang bersemboyan: "Saya Punya Jangan Diganggugugat" -operasi ambil alih mana suka terhadap "milik" rakyat-telah meneguhkan keyakinan bahwa penguasa dengan powernya, adalah penentu segala yang "benar", "baik", dan "tepat". Sedangkan yang lain, dengan polarisasi asimetris binary opposition--"penguasa" dan "yang dikuasai", masyarakat terjebak dalam segmentasi lintas "wilayah" sehingga menimbulkan kecurigaan, kegelisahan, dan kecemasan kolektif (collective anxiety) yang berujung pada kekecewaan sosial-politik.

Dalam ruang politik, UU dan peradilan menjadi instrumen pemaksaan dengan konstruksi sekedar pilihan "ini" atau "itu". ${ }^{20}$ Rakyat-apalagi yang kritis-menjadi kelompok sasaran utama untuk "diajar" menjadi "beradab". Ya, "menyesuaikan diri, atau tamat riwayat". Dalam ruang sosial, kebijakan menyangkut perbedaan pribumi dan nonpribumi meneguhkan segmentasi menurut polarisasi "kami-kamu". Dalam bidang ekonomi puluhan Keppres ala Soeharto menghalalkan pembagian rejeki kekayaan negeri menurut status dan kedekatan dengan lingkaran konco dan kacung penguasa.

Dari sudut integrasi sosial, "kebijakan hukum" seperti ini tidak kurang dari proses penggusuran identitas, harga diri, dan semangat kederajatan-yang bermakna hilangnya mediating structure bagi terbentuknya penyelarasan orientasi bersama dalam suatu bangsa yang pluralis. Mengapa? Oleh karena orientasi bersama itu, dimungkinkan hanya apabila semua komponen bangsa, baik individu maupun kelompok memperlakukan pihak lain sebagai pihak yang tidak boleh dianggap remeh dengan alasan apapun. Orientasi bersama dalam jalinan rasa senasib dan sepenanggungan menjadi krusial bagi integrasi, justru karena integrasi mengasumsikan adanya pluralitas dan heterogenitas. Pluralitas dan heterogenitas dapat menjadi kekuatan integratif, di kala yang satu mengakui yang lain sebagai bagian yang sederajat.

Hukum menggusur semangat integratif, bagaimana mungkin ia dapat berfungsi sebagai mekanisme pengintegrasi? Ketika

${ }^{20}$ Bandingkan dengan "logika" rasionalitas-tujuan dalam teori sistem yang klasik dari Weber, yang mengutamakan pencapaian manfaat yang sebesar-besarnya atas dasar pertimbangan ekonomis. Dalam makna yang demikian, suatu tindakan dikatakan rasional apabila dalam pencapaian tujuannya, dipergunakan caracara yang dapat menekan biaya sampai sekecil-kecilnya. Itulah sebabnya, dalam menejemen akan lebih disukai pendekatan atas-bawah karena arus informasi dari satu pusat selalu mudah dikendalikan dan dikelola, dibandingkan dengan informasi dari pelbágai sumber "di bawah", (lihat dalam Ignas Kleden. 1987. Sikap Ilmiah dan Kritik Kebudayaan. Cetakan 1. Jakarta: LP3ES, HIm. 100). 
"permusuhan" diagungkan lewat hukum, maka yang terjadi adalah kecemburuan yang berpadu dengan kekecewaan (grievances). Ketika kekecewaan tidak diakomodasi oleh penguasa, masyarakat menumpahkannya lewat konflik kekerasan (violence conflicf). Yang disebut terakhir ini, menjelma dalam sindrom "katastropi" (bencana tiba-tiba dan meluas) dan "kataklisme" (kekerasan massa akibat turbulensi sosial-politik) dalam seri kerusuhan bernuansa SARA yang menghiasi jagad negeri. Dengan demikian, kalangan hukum tidak bisa cuci tangan terhadap kerusuhan yang terjadi. Sebab, sampai derajat tertentu kekecewaan yang berujung pada kerusuhan tersebut, merupakan cerminan dari kegagalan konstruksi hukum "milik penguasa " yang "tidak dimengerti" rakyat.

\section{Penutup}

Dari "ideologi" reformasi -yang menghendaki "putus hubungan" dengan kebusukan masa lalu, "pelestarian" hukum represif tidak saja distortif dan terbilang ironis. la juga merupakan penyakit sekaligus ancaman utama yang harus segera diakhiri. Mengapa? Karena momen reformasi inilah yang menentukan berhasil tidaknya bangsa ini merancang-bangun "dunia baru" yang menjunjung demokrasi, supremasi hukum, dan Hak Asasi Manusia. Itu berarti, momen reformasi tidak hanya dipakai untuk melihat secara tajam dan jelas masalah-masalah yang samasekali tidak baik dan tidak beres seperti fakta di atas. la juga-berdasarkan pengenalan masalah yang ada-digunakan untuk merancang-bangun semacam skenario demi mengakhiri rambahan "penyakit kekuasaan" tersebut.
Dengan pertimbangan sistem produksi hukum sekarang yang tertutup dan "state oriented", maka keseimbangan baru yang harus dirancang-bangun adalah, tatanan sistem produksi hukum (baru) yang memberi ruang bagi rakyat untuk semaksimal mungkin "terlibat" dalam proses legislasi. Dengan begitu, legalitas benar-benar dapat berfungsi sebagai alat kontrol kritis-normatif hukumuntuk mencegah "pembiaran" dominasi kekuasaan yang berwatak serba meliputi ( $\mathrm{em}$ bracing) itu. Oleh karena itu menurut hemat penulis, sudah saatnya dipikirkan sejak sekarang agar di satu pihak, menghapuskan sekalian tatanan distortif yang masih dilestarikan, sambil di sisi lain menciptakan tatanan yang kokoh bagi terbangunnya "proses legislasi yang bersifat publik".

Pada aras supra struktur, khususnya UUD'45 perlu dilakukan amandemen. Sebagai negara yang memiliki institusi-institusi modern, managemen penyelenggaraan negara harus ditopang oleh mekanisme kontrol institusional yang jelas dan mandiri. Oleh karena itu, perlu segera dilakukan penataan kembali hubungan supra struktur politik, legislatif, eksekutif, dan yudikatif melalui perubahan-perubahan sebagai berikut:

Pertama, segera merubah "kerangka keyakinan" dalam penyelenggaraan negara yang digantungkan pada kehendak baik penyelenggaranya untuk menghindari voluntarisme subyektif dan penyalahgunaan kekuasaan. Seperti diketahui, "kerangka keyakinan" managemen negara versi UUD'45 dikonstruksi dalam sebuah pengandaian "utopis" tentang pimpinan yang baik, tulus, dan tidak memiliki kepentingan sendiri. Sebuah pengandaian yang secara kontemporer tidak lagi menemukan pembenaran empirik- 
seperti dibuktikan oleh abuse of power dan praktik KKN sejak pemerintahan Soekarno, Soeharto, hingga pemerintahan Habibie.

Kemunculan mereka sebagai pimpinan bangsa tidak bisa dipungkiri dilandasi semangat yang luhur. Namun dalam kendaraan UU''45, ketiganya jatuh ke lubang yang sama, yaitu naluri preservasi kekuasaan yang mengamini "postulat"-nya Lord Acton: "power tends to corrupt, and absolute power corrups absolutely". Sebagai negara yang memiliki institusi-institusi modem, managemen penyelenggaraan negara harus ditopang oleh mekanisme kontrol institusional yang jelas dan ketat.

Kedua, mengganti asas pembagian kekuasaan oleh prinsip pemisahan kekuasaan. untuk' menjamin berjalannya mekanisme check and balance antar supra-struktur politik. Oleh karena itu, periu segera dilakukan penataan kembali hubungan supra struktur politik antara legislatif, eksekutif, dan yudikatif menurut prinsip Trias Politika.

Pengalaman Orba telah membuktikan, bahwa prinsip pembagian kekuasaan membungkus paling sedikit dua penyakit endemik-yang ujung-ujungnya membuka peluang pada dominasi eksekutif. Yang satu, adalah kekaburan batas wewenang, kepentingan, dan tugas antara legislatif, eksekutif, dan yudikatif. Kekaburan itu menghasilkan kewenangan eksekutif yang serba meliputi, baik di wilayah legislasi mau pun yudikasi.

Sedangkan yang lain, ialah munculnya konsepsi "kemitraan" antara legislatif dan eksekutif —ketika "menerjemahkan" statuta pasal 5 (1) UUD'45 - presiden "bersama" DPR membuat UU. Dengan konsepsi yang demikian, bukan saja kian mengaburkan pembagian wewenang, kepentingan, dan tugas antara keduanya. la juga, dan inilah yang terutama, adalah keduanya sama-sama menjalankan kékuasaan, dan keduanya "bergotong-royong" mengawasi penggunaan kekuasaan. Dengan memakai istilah populer kontemporer reformasi, meminjam istilah lgnas Kleden, antara keduanya terjadi semacam kolusi.

Ketiga, mencegah "negararisasi" hukum. melalui pembatasan kewenangan membuat UU organik, khususnya menyangkut hak-hak dasar masyarakat dan kewajiban-kewajiban utama negara. UUD'45 terlalu banyak mendelegasikan kewenangan kepada negara untuk menjabarkan prinsip-prinsip dasarnya. lewat UU organik.

Kewenangan tersebut diatur dalam tidak kurang 11 pasal yang meliputi berbagai bidang: yang sangat vital. Semisal keanggotaan MPR (ps. 2), syarat-syarat pemberlakuan keadaan darurat (ps. 12), otonomi dan hak asal-usul masyarakat lokal (ps. 18), susunan dan komposisi DPR (ps. 19), keanggotaan-dan kewenangan. BPK (ps. 23), keanggotaan dan kekuasaan MA dan kehakiman (ps. 24-25) dan hal-hal lain menyangkut hak warga negara.

Kiprah rezim Orba "menerjemahkan" prinsip-prinsip dasar tersebut, tidak saja memupuk manipulasi konstitusi, tetapi juga mengakibatkan penguasaan negara terhadap masyarakat. Dengan bersembunyi pada ketakberdayaan DPR-yang by design dibuat kalah saing dengan eksekutif, substansi UU organik ditentukan menurut selera penguasa. Contoh mengenai hal ini amat banyak. Semisal, konservasi kekuasaan lewat penentuan keanggotaan DPR dan MPR melalui pengangkatan. Dengan kewenangan yang diijinkan pasal 2 dan 19 UUD'45, tidak saja 
menyuburkan diskriminasi politik, tetapi juga menjadi pengaman konservasi kekuasaan status quo.

Demikian pula represi dan pengebirian hak-hak masyarakat dan rakyat berjalan leluasa: mulai dari hak politik (ps..28), sosial (ps. 31), otonomi (ps. 18), dan pertahanan keamanan (ps. 30). Secara demikian, hak dan kedaulatan rakyat ditelan habis oleh negara dan penguasa, sehingga harus dibayar mahal dengan hancumya civil society dan terabaikannya kepentingan-kepentingan non-negara, semisal hak-hak individu, HAM, dan otonomi masyarakat lokal.

Keempat, mengatur dan membatasi kekuasaan presiden untuk mencegah penumpukan kekuasaan yang tidak proporsional. Di tangan presiden versi UUD'45, terhimpun bermacam-macam kekuasaan, entah sebagai kepala negara -yang memiliki kewenangan yudikatif, kepala pemerintahanyang memiliki wewenang legislatif, panglima tertinggi $A B R I$, dan lain-lain. Dengan demikian, di tangan presiden terakumulasi tumpukan hak prerogatif yang justru tidak bisa tersentuh lembaga kontrol di luarnya.

Keadaan itu kian diperparah oleh tiadanya prinsip lex certa (perumusan yang jelas dan ketat) mengenai masa jabatan presiden. Pasal 7 hanya mengandung rumusan karet yang serba embracing. Oleh karena itu, siapa pun rezim yang berkuasa niscaya mendapat keuntungan yang besar dari kelonggaran interpretasi yang disediakan oleh UUD' 45 .

Ini sudah terbukti ketika presiden pertama dan kedua mempertahankan kekuasaan secara habis-habisan tanpa merasa inkonstitusional--karena memang rumusannya memberi peluang yang besar bagi rezim untuk menjaga posisi yang ada. Kombinasi antara kepentingan subyektif untuk mempertahankan kekuasaan dan kelonggaran rumusan pasalpasal konstitusi, membuat rezim yang sedang berkuasa tetap memiliki akses tak terbatas menghimpun kekuasaan untuk mempertahankan status quo.

Kelima, memurnikan lembaga DPR/MPR sebagai lembaga rakyat dengan menghapus utusan golongan dan utusan daerah, serta wakil dari kalangan militer/polisi. Sebab, pembiaran "keanggotaan promosi" yang demikian, selain menimbulkan distorsi aspirasi rakyat, juga membuka peluang masuknya naluri represif kekuasaan.

Keenam, perlu diatur mekanisme yang memungkinkan rakyat terlibat langsung dalam menentukan tiap kebijakan baik yang berada dalam wilayah legislatif maupun eksekutif. Ini penting, bukan saja karena 500 orang anggota legislatif tidak mungkin mewakili aspirasi 210 juta rakyat Indonesia, tetapi juga agar rakyat sebagai pemilik kedaulatan dapat mengontrol wakil-wakilnya, sekaligus menyampaikan langsung aspirasinya. Tentu saja, termasuk di sini adalah pemilihan presiden secara langsung.

Ketujuh, membangun mekanisme yang memaksa legislatif untuk mengaktifkan fungsi kontrolnya. Tumpukan krisis dan praktik kotor KKN yang diturun-alihkan rezim Soeharto ke tangan pemerintahan Habibie, sedikit banyak berbiak dari keengganan "wakil rakyat" menggunakan hak-hak kontrolnya.

Kedelapan, menjadikan proses legislasi sebagai "ruang publik". Ini penting, bukan saja karena pengalaman masa lalu di mana DPR selalu kalah saing oleh eksekutif. la juga, dan inilah yang sangat penting, yakni agar produk hukum lebih bermuatan aspirasi rakyat ketimbang konsesi kepentingan pemerintah dan DPR. Sedangkan yang terakhir, 
kesembilan, periu regulasi yang rinci mengenai HAM dengan mengadopsi instrumen-instrumen internasional yang ada.

Inilah sejumlah agenda mendasar reformasi kelembagaan, menuju terbangunnya "model" -yang baru- yang berfungsi sebagai "the central cognitive resource" penyelenggaraan hukum ke depan.

\section{Daftar Pustaka}

Nonet, Philippe \& Philip Selznick. 1978. Law and Society in Transition: Toward Responsive Law, London: Harper and Row Publisher.

Dahrendorf, Ralf . 1954. Class and Class Conflict in Industrial Society Stanford: University Press.

Poggi, Gianfranco. 1978. The Development of the Modern State, A Sociological Introduction. London: Hurchinson \& Co. Ltd.

Keijzer, Nico. 1989. "Legaliteitsbeginsel." Makalah pada Penataran Nasional Hukum Pidana Angkatan:, III
Kerjasama indonesia-Belanda di Kupang, 30 Juli sampai dengan 19 Agustus, hal. 3 - 4 .

Santos, B. De Sousa. 1995. Toward A New Common Sense: Law, Science and Politics In Paradigmatic Transition. New York: Routledge.

Neumann, Franc L. 1986. The Rule of Law, Political Theory and Legal System in Modern Society. New Hampshire: Berg Publisher Ltd.

Hardiman, F.B. 1993. "Mengatasi Paradoks Modernisasi", dalam Diskursus Kemasyarakatan dan Kemanusiaan. Jakarta: Gramedia.

Sampford. 1989. The Disorder of Law: A Critique of Legal Theory. New York: Basill Blackwell Inc.

Kleden, Ignas. 1987. Sikap IImiah dan Kritik Kebudayaan. Cetakan .1. Jakarta: LP3ES, HIm. 100).

本 辛 